\title{
USGS/NOAA NORTH AMERICAN PACKRAT MIDDEN DATABASE DATA DICTIONARY
}

by Laura E. Strickland ${ }^{1}$, Robert S. Thompson ${ }^{1}$, and Katherine H. Anderson ${ }^{2}$

Open-File Report 01- 022

2001

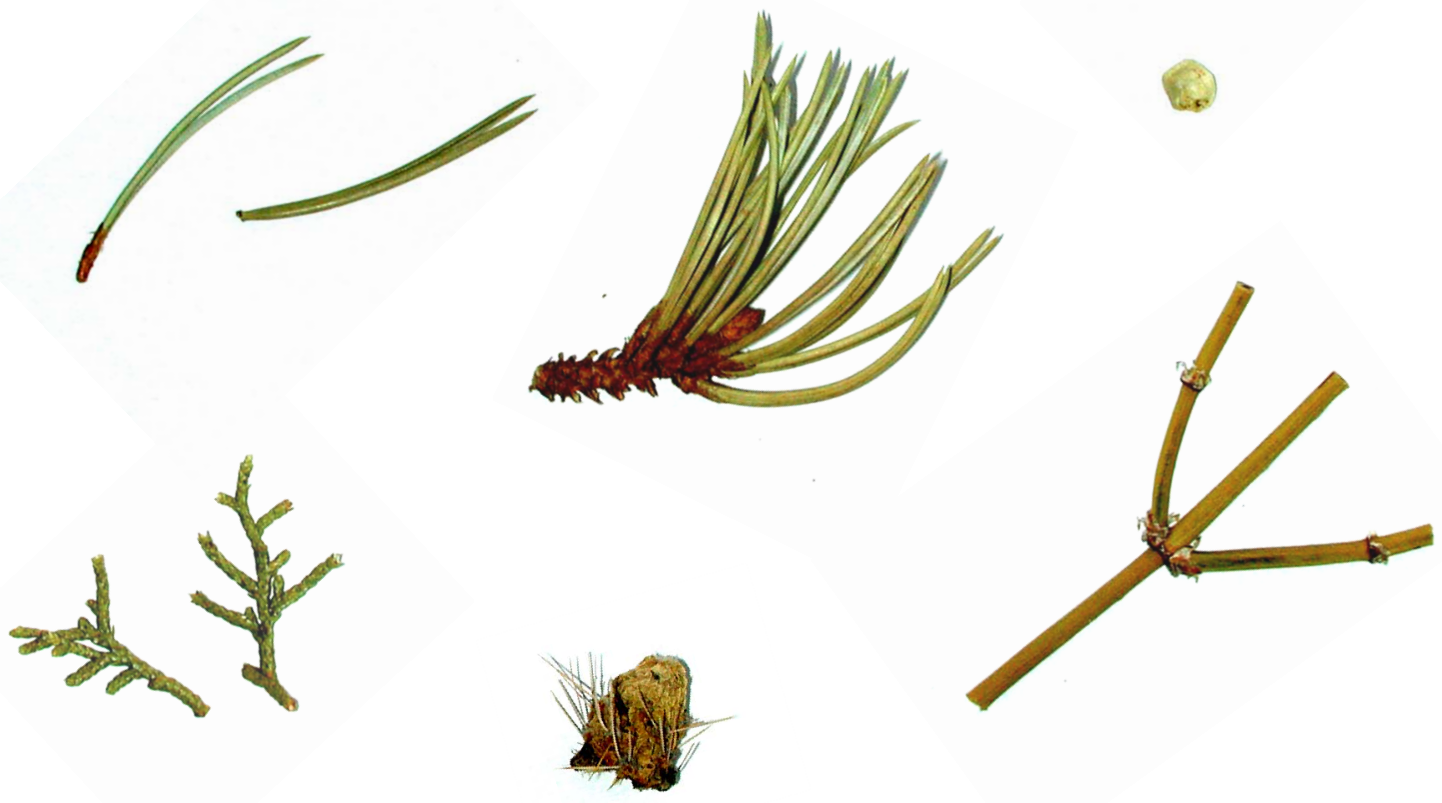

This report is preliminary and has not been reviewed for conformity with U.S. Geological Survey editorial standards or with the North American Stratigraphic Code. Any use of trade, firm, or product names is for descriptive purposes only and does not imply endorsement by the U.S. Government.

\section{U.S. DEPARTMENT OF THE INTERIOR}

\section{U.S. GEOLOGICAL SURVEY}

${ }^{1}$ Denver, Colorado

${ }^{2}$ Institute of Arctic and Alpine Research, University of Colorado, Boulder, Colorado 


\section{INTRODUCTION}

Packrats, also known as wood rats or trade rats, are herbivorous Sigmodontine rodents belonging to the genus Neotoma (Vaughan, 1990). Twenty-one North American species of packrat are widely distributed from the Northwest Territories of Canada $\left(65^{\circ} 23^{\prime} \mathrm{N}\right)$ to tropical Nicaragua $\left(13^{\circ} \mathrm{N}\right)$ (Vaughan, 1990). Arid and semi-arid lands of the southwestern United States presently support six different packrat species, which have probably persisted in the region, at least intermittently throughout the past 40,000 years (Vaughan, 1990).

Vaughan (1990) summarizes the ecology of modern packrats in North America and the southwestern U.S. All modern packrats demonstrate a habit, unique among rodents, of collecting various items from their surrounding environment. These animals gather a variety of materials including plant debris, rocks, bones, insect parts, and human artifacts, generally from within a limited foraging range $(30-50 \mathrm{~m})$ of their dens. Not every packrat species has the same dietary preferences or collecting habits, and some species sample their environments better than others by collecting a greater variety of plant materials from the surrounding landscape. Materials collected by the packrat are brought back to the den, which may occupy a cave or rock shelter, or consist of a house situated in an open area, built of woody plant materials such as branches or cactus joints. The packrat deposits the collected items, along with fecal material, urine, and food wastes to form a refuse heap called a midden. The animal compacts the midden debris and its viscous urine functions to cement the midden material together to form a gray to dark brown solid mass (Spaulding et al., 1990).

Middens deposited in dry caves and rock shelters can remain intact for tens-of-thousands of years (Finley, 1990). Mummified remains of ancient plants and animals encased in packrat middens are often perfectly preserved and can usually be identified to species. These fossil plant and animal remains provide excellent materials for radiocarbon dating, and assemblages of remains supply detailed inventories of the plants and animals that lived at the collection site for discrete points in the past. Fossil middens often contain remains of plants that do not presently live in the vicinity of the site, indicating that the surrounding flora has changed since the time of deposition. Studying midden assemblages of various ages therefore, can provide detailed records of vegetation change through time.

In the arid regions of the southwestern United States plant macrofossil assemblages recovered from packrat middens are among the best sources of information on late Pleistocene 
and Holocene vegetation changes. Urine cemented middens of ancient packrats are frequently found in dry caves, rock shelters and rock crevices throughout the region. Over the past forty years, scientific study of ancient packrat middens has revealed a wealth of information on the history of late Quaternary vegetation change in the southwestern U.S. Unfortunately, scientists studying packrat middens use many different methods of collecting and analyzing midden data, which makes it difficult to compare data and conduct analyses utilizing data, produced by midden investigators using different scientific methods.

The North American Packrat Midden Database is a joint project developed by the U.S. Geological Survey and the National Oceanic and Atmospheric Administration, with the purpose to provide researchers with access to standardized midden data that can be useful for investigating late Quaternary changes in plant species distributions in response to climate and environmental change. The database currently contains original data from more than 900 packrat midden samples collected from over 270 local areas (caves or rock shelters) ranging from Montana to Northern Mexico (Figure 1). Midden data including locality information, midden sample ages and plant taxa lists, were collected from 66 published and unpublished sources. Data were entered into a Microsoft Access database with the intent to preserve the data in the original format used by each investigator. In order to facilitate the comparison and use of data from different sources, the database translates original species relative abundance data into a uniform format. This document describes the structure of the North American Packrat Midden Database, the methods used to compile the data, and provides a data dictionary.

\section{STRUCTURE}

The North American Packrat Midden Database consists of nine tables where identical fields are linked with simple joins (Table 1 and Figure 2). Joined fields contain unique values, which allow the data tables to be linked. Each publication, midden sample and plant taxon is distinguished by a unique code. Publications are represented by reference numbers (refnum), midden samples by sample codes (samcode), and plant taxa by variable numbers (varnum). Seven of the nine tables contain data and two of the nine tables are look up tables (Table 1).

A data dictionary, which describes the content of the individual fields comprising each data table is provided in the following pages. Sample tables 2 through 8 , in the final section of 
this report, display the layout of each data table and provide samples of the type of data entered in each table. 
Figure 1. Packrat midden localities in western North America.
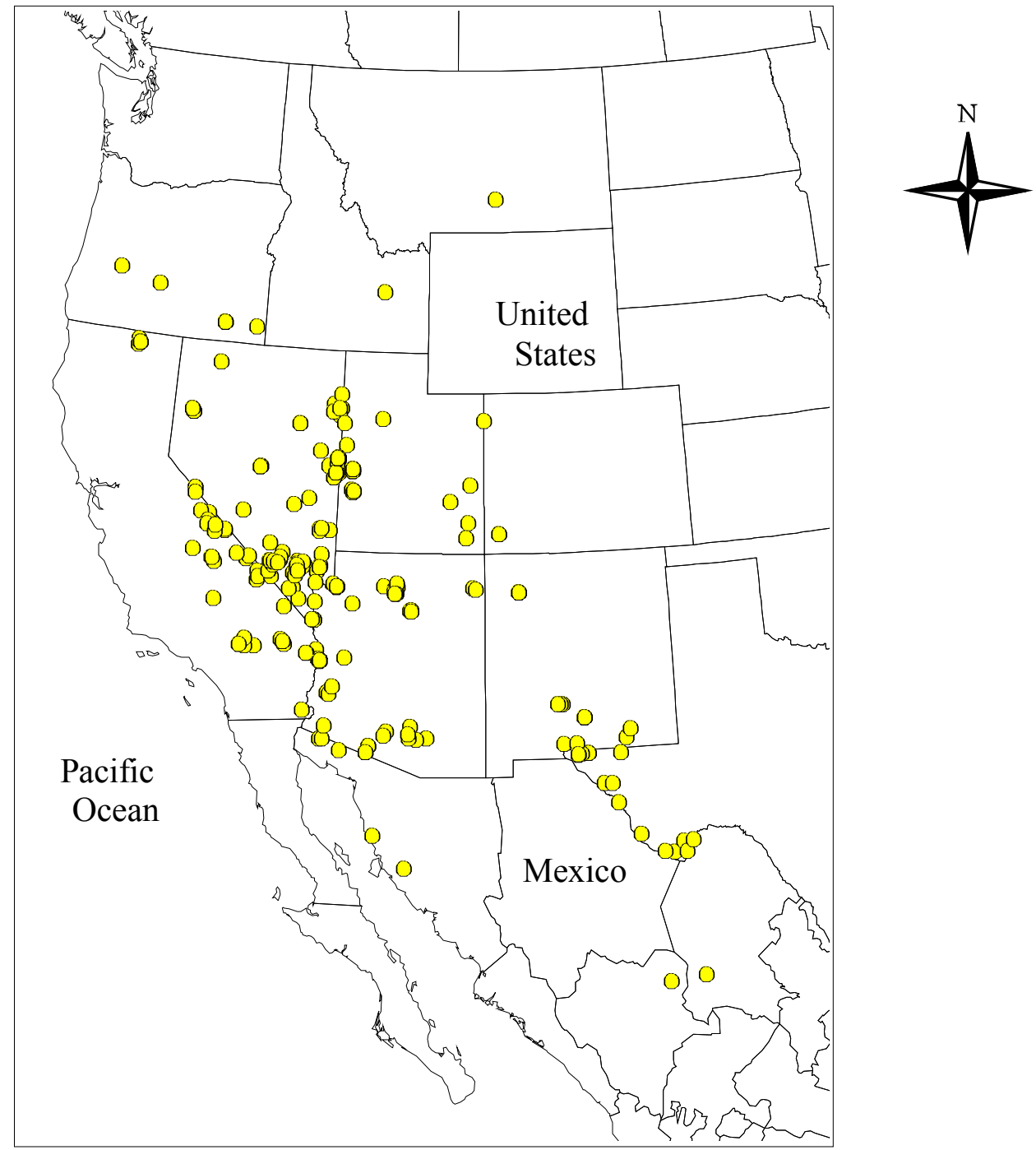

- Midden localities currently in the database 
Table 1. Data table and look up table descriptions.

$\underline{\text { Data Tables }}$

1. REFERENCE

2. MIDDEN SAMPLE SITES

3. $\mathrm{AGE}{ }^{14} \mathrm{C}$

4. MIDDEN TAXA

5. TAXA PER SITE

6. CODE TRANSLATION

7. M COUNT TRANSLATION

\section{Content}

List of source publications.

Locality information.

Age data.

A comprehensive list of plant taxa recovered from packrat middens.

Lists plant taxa collected, relative abundance and organ type (needle, seed, leaf etc.)

Describes original counting schemes and translates each scheme into 0-1-2 relative abundance scale.

Translates orginal macrofossil counts from each midden sample into the $0-1-2$ relative abundance scale.

$\underline{\text { Look up Tables }}$

1. USE STATUS

2. 0-1-2 CODE
Describes the usefulness of the data.

Defines the 0-1-2 relative abundance scale. 
Figure 2. North American Packrat Midden Database table relationships.

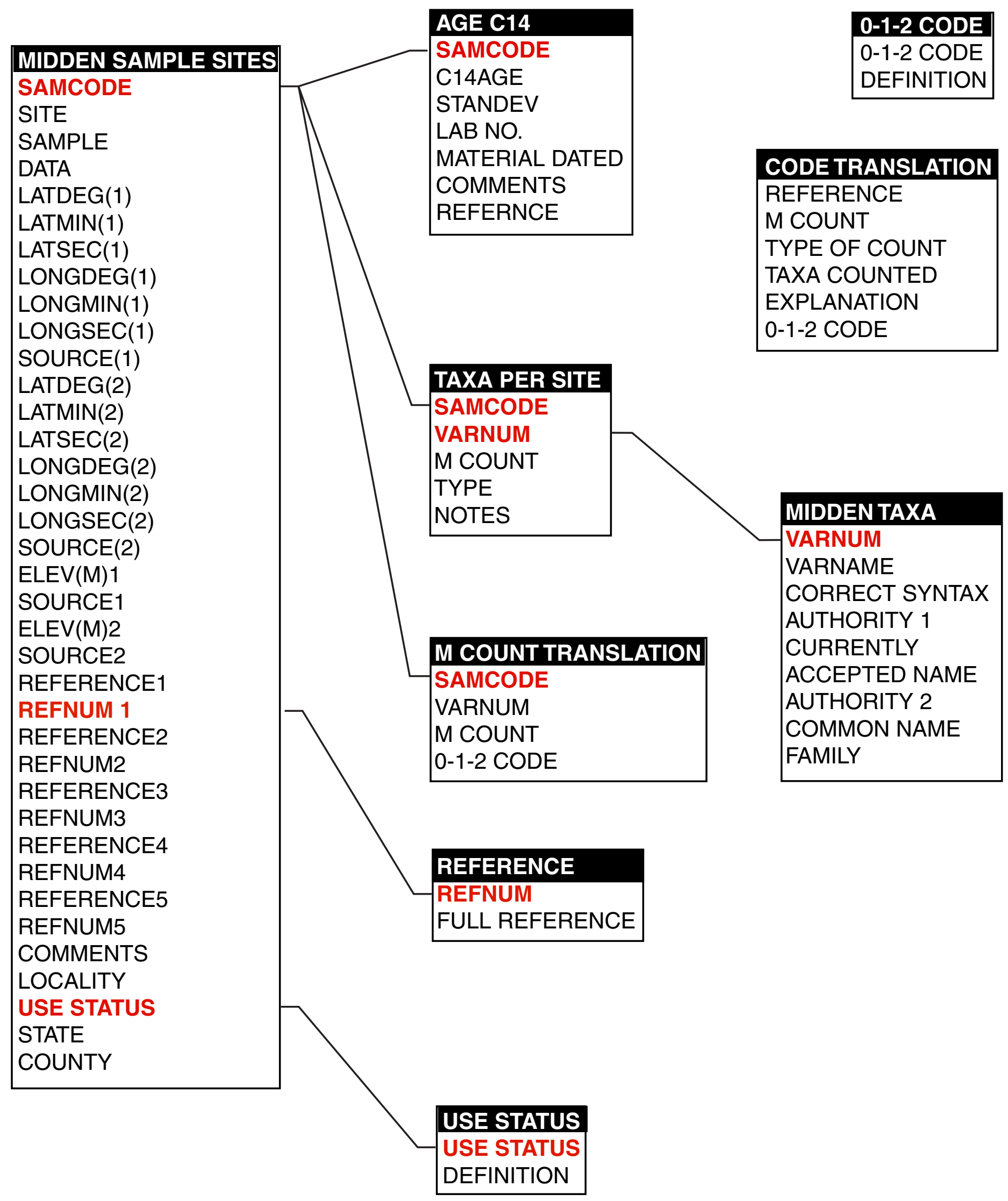




\section{DATA DICTIONARY: TABLE AND FIELD DESCRIPTIONS}

\section{$\underline{\text { Reference Table }}$}

Midden data from 66 published and unpublished sources has been entered in the database. Full references for all data sources can be found in the reference table. The reference table consists of the following fields.

Fields $\quad$ Description

1. REFNUM: Reference Number. A unique number assigned to each reference.

2. FULL REFERENCE: Includes the author or authors, date of publication, title, journal or publication series.

Table 2 lists some sample references, as they would appear in the reference table.

\section{Midden Sample Sites Table}

The Midden Sample Sites Table provides locality information for each midden sample and contains the following 33 fields.

$\underline{\text { Fields }}$

1. SAMCODE:

2. SITE:

3. SAMPLE:

4. DATA:

5. LAT DEG(1):

6. LAT MIN(1):

7. LAT SEC(1):

8. LONG DEG(1):

9. LONG MIN(1):

10. LONG SEC(1):

11. SOURCE(1):

12. $\operatorname{LAT} \operatorname{DEG}(2)$ :

\section{Description}

Sample Code. A unique code assigned to each midden sample.

Site name.

Original sample identification code.

An $X$ in this field means a list of plant macrofossil taxa collected from the midden is available.

Degrees of latitude.

Minutes of latitude.

Seconds of latitude.

Degrees of longitude.

Minutes of longitude.

Seconds of longitude.

Source of latitude/longitude data

Degrees of latitude. 
13. $\operatorname{LAT} \operatorname{MIN}(2)$ : Minutes of latitude.

14. LAT SEC(2): Seconds of latitude.

15. LONG DEG(2): Degrees of longitude.

16. $\operatorname{LONG} \mathrm{MIN}(2)$ : Minutes of longitude.

17. LONG SEC(2): Seconds of longitude.

18. SOURCE(2): Source of latitude/longitude data.

19. $\operatorname{ELEV}(\mathrm{M}) 1$ : Elevation in meters.

20. SOURCE1: Source of elevation data.

21. $\operatorname{ELEV}(\mathrm{M}) 2$ : Elevation in meters.

22. SOURCE2: Source of elevation data.

23. REFERENCE1: Author and date of publication where the data was most recently published.

24. REFNUM: Reference number of first reference.

25. REFERENCE2: Previous publication of data.

26. REFNUM2: Reference number of second reference.

27. REFERENCE3: Previous publication of data.

28. REFNUM3: Reference number of third reference.

29. COMMENTS: Miscellaneous comments. For information only.

30. LOCALITY: Geographic region. For information only.

31. USE STATUS: Describes the completeness of the data available.

1 OK to Use; Site/Dating/Complete taxa list exist

2 OK to Use; Site/Dating but no taxa list

3 Unpublished taxa list, not entered

$4 \quad$ Site info only

5 Processing

6 Data needs to be put into electronic format

7 Counting in progress by author

8 Still working on questions

* -9 Only partial taxa list published 
* Some taxa lists include all plant taxa found in a midden sample, for some midden samples only partial taxa lists are available. Partial taxa lists are included in the database and designated with a -9 in the use status category.

\section{STATE: 2-letter state code. For information only.}

33. COUNTY: County name. For information only.

When available, midden sample locality information including elevation, latitude and longitude, state, county and geographic region (mountain range, drainage etc.) were recorded directly from written reports. In some instances locality information was interpreted from accompanying maps or topographic maps. Sometimes information about a specific midden sample may be available in multiple written reports. Referencel usually lists the most recently published information on a particular midden sample. Additional sources of information are listed as additional references. Pieces of information such as latitude, longitude and elevation may also be found in multiple publications and this information is not always consistent. If this information is found in more than one source and the most accurate data cannot be determined all available information and sources will be included in the Midden Sample Sites Table. Table 3 shows how sample data are arranged in the Midden Sample Sites Table.

$\underline{\text { Age }{ }^{14} \mathrm{C} \text { Table }}$

This table provides information about carbon-14 dates on individual midden samples. It is linked to the Midden Sample Sites table by the sample code. Age data were taken directly from written reports and include carbon-14 dates with standard deviations, laboratory numbers, the material dated and the source reference. Sample age data are shown in Table 4.

$\underline{\text { Fields }}$

1. SAMCODE:

2. ${ }^{14} \mathrm{C}$ AGE:

3. STANDEV:

4. LAB NO.:
Description

Sample Code. A unique code assigned to each midden sample.

Age in years before present.

Standard Deviation. Range of possible error.

A number assigned by the laboratory. 

5. MATERIAL DATED:
May consist of various plant materials, dung or matrix.
6. COMMENTS:
Miscellaneous Comments. For information only.
7. REFERENCE: Source of data.

\section{Midden Taxa Table}

The Midden Taxa Table is a comprehensive list of all plant taxa that have been recovered from all midden samples included in this database and consists of the following eight fields. Table 5 shows sample data from the Midden Taxa Table.

Fields

1. VARNUM:

2. VARNAME:

3. ORIGINAL SYNTAX:

4. AUTHORITY 1:

\section{CURRENTLY ACCEPTED} NOMENCLATURE:

6. AUTHORITY 2:

7. COMMON NAME:

8. FAMILY:

\section{Description}

Variable number - a unique number assigned to each taxon.

Variable name - the original botanical name used by the macrofossil analyst.

The original syntax used by the macrofossil analyst, if it is different from the syntax accepted in the database.

The name (or names) which identify the person (or persons) who described the plant species. Should the original species name be revised, the name of the original authority is shown in parentheses followed by the name of the authority who created the existing combination of genus and species names. The names of these authors are often abbreviated.

The currently accepted latin or botanical name.

Author of currently accepted varname.

Common name (or names).

Family of the taxon.

Each unique taxon has been assigned a unique variable number (varnum). Original botanical names used by macrofossil analysts have been entered into the varname field. If the syntax used by the analyst does not conform to the syntactic rules of the database, the original syntax may be modified to conform to the database only, if the modification does not change the 
meaning of the level of identification. If it is necessary to change the syntax of a botanical name, the original syntax will be shown in the original syntax field. If the botanical nomenclature used by the analyst is no longer current due to taxonomic changes, the original botanical name used by the analyst will be preserved in the varname field, and the new botanical name will be specified in the currently accepted nomenclature field. Authorities of old and new botanical names, common names and family names are also included in the Midden Taxa Table. An explanation of the taxonomic rules used in the design of the Midden Taxa Table follows.

\section{Taxonomic Rules: Synonomy}

Two kinds of synonomy are used in the Midden Taxa Table, nomenclatural and syntactic. Lists of botanical names submitted to the database should conform to the nomenclatural and syntactic conventions used in the database. If contributors' names do not conform to the conventions of the database, names will be modified according to the following taxonomic rules.

Nomenclatural synonomy refers to botanical nomenclature. Botanical Nomenclature follows Kartesz, (1999). The database equates old and new botanical names. When performing a search of a particular taxon all synonyms will be considered.

Examples of Nomenclatural Synonomy:

Family level synonomy:

1. Asteraceae $=$ Compositae

2. Poaceae $=$ Gramineae

Genus level synonomy:

1. Berberis trifoliolata $=$ Mahonia trifoliolata

2. Forsellesia $\mathrm{sp} .=$ Glossopetalon $\mathrm{sp}$.

Species level synonomy:

1. Larrea tridentata $=$ Larrea divaricata

2. Gutierrezia bracteata $=$ Gutierrezia californica

Syntactic Synonomy refers to syntax that applies to the non-Latin parts of botanical names. In the determination of plant macrofossils, syntax helps to define the degree of certainty 
of the identification. Examples of syntax commonly used in the identification of plant macrofossils from packrat middens are listed below. The syntactic rules used in this database generally follow the rules defined by Birks and Birks, (1980); The North American Pollen Database Manual, (1997); and Watts and Winter, (1966). When submitting taxa lists please follow the recommended syntactic rules outlined as follows.

Family level use of syntax:

1. If a specimen (or specimens) can only be identified to family level the following syntax is often used.

$*$ Family $=>$ Asteraceae

Family sp. => Asteraceae sp.

* Use of the family name alone (Family $=>$ Asteraceae) is preferred. Data that do not conform to this syntax will be modified. Family sp. => Asteraceae sp. will be changed to Family $=>$ Asteraceae.

2. When multiple specimens can be identified to family level and more than one morphological type can be distinguished the abbreviation undiff. (undifferentiated) may be used. Family undiff. is acceptable syntax.

Family undiff. (undifferentiated) $=>$ Asteraceae undiff.

3. When a specimen/s belongs to one of two similar families and assignment to a single family cannot be made, the following syntax is often used.

* Family/Family => Chenopodiaceae/Amaranthaceae

Family or Family $=>$ Chenopodiaceae or Amaranthaceae

Family - Family => Chenopodiaceae - Amaranthaceae

* If a distinction between two similar families cannot be made on the basis of morphology alone, a slash should be used between multiple family names rather than "or" and "-". Data that do not conform to this syntax will be modified.

Genus and species level use of syntax:

1. When the genus and species are certain, the taxon should be written as:

Genus species => Quercus alba 
2. When the genus is certain and the species cannot be determined, the taxon should be written as:

$$
\text { Genus sp. => Quercus sp. }
$$

3. When multiple specimens belong to the same genus but multiple species may be present the following syntax is commonly used.

Genus spp. (multiple species) => Quercus spp.

* Genus undiff. (undifferentiated) $\Rightarrow$ Quercus undiff.

* The database uses Genus undiff. rather than Genus spp. Data that does not conform to this syntax will be modified.

3. When a specimen (or specimens) belongs to one of two similar genera the following syntax is commonly used.

* Genus/Genus $=>$ Ostrya/Carpinus

Genus or Genus => Ostrya or Carpinus

Genus - Genus $=>$ Ostrya - Carpinus

* If a distinction between two similar genera cannot be made on the basis of morphology alone, a slash should be used between multiple genus names, rather than "or" and "-". Data that do not conform to this syntax will be modified. The database also accepts:

Genus species/Genus species $=>$ Rhus aromatica/Rhus virens

Placement of cf.:

If the family, genus or species is uncertain but the specimen resembles a specific family, genus or species, cf. (compares to) can be used to show that the specimen has the form of a particular family, genus or species. Use of cf. implies uncertainty because of poor preservation, inadequate reference material or ill-defined morphology.

1. If the species is uncertain cf. should be placed before the species name.

Genus cf. species $=>$ Quercus cf. alba 
It is considered proper syntax to abbreviate the genus name when using cf. However, most macrofossil analysts do not abbreviate the genus when using cf. therefore, the genus abbreviation will not be used in this database.

Genus cf. G. species $=>$ Quercus cf. Q. alba => Quercus cf. alba

2. If the genus or family is uncertain cf. should be placed in front of the genus or family name as follows:

$$
\begin{aligned}
& \text { cf. genus }=>\text { cf. Quercus } \\
& \text { cf. Family }=>\text { cf. Asteraceae }
\end{aligned}
$$

Family cf. genus $=>$ Asteraceae cf. Brickellia

Do not use parentheses around cf. behind the genus or family name such as:

$$
\begin{aligned}
& \text { Genus (cf.) => Quercus (cf.) } \\
& \text { Family (cf.) => Asteraceae (cf.) }
\end{aligned}
$$

Use of type:

Type is used when one fossil type is present and three or more taxa are possible alternatives. Type should always be placed after the family, genus or species and preceded by a hyphen (North American Pollen Database Manual, 1997). Data that do not conform to this syntax will be modified. The following examples are all accepted in the database.

1. Family - type $=>$ Asteraceae - type

2. Genus - type $=>$ Quercus - type

Rather than: Genus type => Quercus type

$$
\text { Genus }(\text { type })=>\text { Quercus }(\text { type })
$$

Genus s.l. (sensu lato - in the broad sense) => Quercus s.l.

3. Genus species - type $=>$ Quercus alba - type

4. Genus/Genus - type $=>$ Avena/Festuca - type

Rather than: Genus - type/Genus - type => Avena - type/Festuca - type 
Other acceptable syntax:

$$
\begin{aligned}
& \text { subf. = subfamily } \\
& \text { ssp. = subspecies } \\
& \text { var. = variety }
\end{aligned}
$$

These abbreviations should be placed in front of the appropriate subfamily, subspecies or variety name.

$$
\text { indet. }=\text { indeterminable }
$$

The use of indet. implies that the specimen (or speciemens) is too poorly preserved to be indentified to a lower taxonomic level. The level of taxonomic uncertainty should be specified as follows:

Family, genus indet. => Asteraceae, genus indet.

Genus, species indet. => Quercus, species indet.

\section{Taxa Per Site Table}

The Taxa Per Site Table lists the plant taxa by variable number, collected from each midden sample and consists of the following five fields.

\section{Fields}

1. SAMCODE:

2. VARNUM:

3. M COUNT:

4. TYPE:

5. NOTES:
Description

Sample Code. A unique code assigned to each midden sample.

A unique number corresponding to a specific taxon. Macrofossil Count. Original symbols or numbers used to represent relative abundance.

Plant organs identified (needle, seed, leaf etc.)

Miscellaneous notes. For Information Only.

Lists of plant taxa collected from midden samples were input directly from source references. If a list of plant taxa collected from a specific midden sample was published in more than one source, the most recently published taxa list was entered into the database and assumed to be the most accurate list. The relative abundance of each taxon has been entered into the $\mathrm{M}$ Count field and the type of plant organ or organs identified was included in the Type field when available. Table 6 displays how taxa lists appear in the Taxa Per Site Table. 


\section{Code Translation Table}

Packrat midden analysts use a variety of counting schemes to represent the relative abundance of plant macrofossil taxa collected from midden samples. The Code Translation Table describes the type of counting scheme used by each macrofossil analyst. Some common schemes use numeric codes or symbols to represent relative abundance. Examples of common counting schemes are shown in table 7.

$\underline{\text { Fields }}$

1. REFERENCE:

2. M COUNT:

3. TYPE OF COUNT:

4. TAXA COUNTED:

5. EXPLANATION:

6. 0-1-2 CODE:

\section{Description}

Author or authors, date of publication, title, journal or publication series.

Macrofossil Count. Original symbols or numbers used to represent relative abundance.

General type of counting scheme used.

Specifies whether all plant remains were counted or only specific taxa.

Defines the symbols used to represent relative abundance.

The $\mathrm{M}$ count translated into a 0-1-2 relative abundance scale.

$$
\begin{aligned}
0 & =\text { Absent } \\
1 & =\text { Rare } \\
2 & =\text { Present } \\
7 & =\text { Can't translate } \\
9 & =\text { Possible contaminant } \\
99 & =\text { Need to make a decision }
\end{aligned}
$$

In order to facilitate the use and comparison of relative abundance data from midden samples analyzed using different counting methods, each counting scheme was translated into a uniform 0-1-2 relative abundance scale resulting in a standardized dataset. 


\section{Rules for Translating the M Count into the 0-1-2 Relative Abundance Scale}

1. For counting schemes that use symbols such as *, X, and +, one symbol is represented in the 0-1-2 code by the number 1 (rare), and two or more symbols translate to the number 2 (present).

2. For numeric relative abundance scales, the number 1 is represented in the 0-1-2 code by the number 1 (rare) and the number 2 or greater translates to the number 2 (present).

3. For percent abundance scales and raw counts, less than or equal to five $\%$ or five specimens translates as number 1 (rare). Greater than $5 \%$ or more than 5 specimens translates as number 2 (present).

4. For macrofossil weight in grams, $<$ or $=$ to .003 translates to the number 1 (rare) and $>.003$ translates to the number 2 (present).

5. For macrofossil weights measured on a $\log$ base $10 / \mathrm{kg}$ scale, $<$ or $=$ to 1.60 translates to the number 1 (rare) and $>1.60$ translates to the number 2 (present). The value 1.60 $=5$ macrofossils $/ \mathrm{kg}$.

\section{$\underline{\text { M Count Translation Table }}$}

This table lists the taxa recovered from each site, the M Count, and the equivalent 0-1-2 Code. Taxa in the M Count Translation Table are listed by variable number. Table 8 shows sample data from the M Count Translation Table.

\section{$\underline{\text { Fields }}$}

1. SAMCODE:

2. VARNUM:

3. M COUNT:

4. 0-1-2 CODE:
Description

Sample Code. A unique code assigned to each sample.

Variable Number. A unique number assigned to each taxon.

Macrofossil Count. Original symbols or numbers used to represent relative abundance.

The original macrofossil counts translated into the 0-1-2 relative abundance scale. 


\title{
ACCESSING THE DATABASE
}

The North American Packrat Midden Database can be accessed via the Internet at http://climchange.cr.usgs.gov/data/midden/ The data can be queried by publication (author and date of publication), taxon, geographic area (state/country), locality name, latitude/longitude, and

${ }^{14} \mathrm{C}$ age. Data file output options are web pages, tab-delimited ASCII files, and comma-delimited ASCII files.

\section{SUBMITTING DATA}

When submitting data, please provide data in a Microsoft Excel Spreadsheet. Please follow the structure and format of the data tables outlined in this report. Submit data to:

\author{
Laura Strickland \\ U.S. Geological Survey \\ Earth Surface Processes Team \\ Box 25046, MS 980 \\ Denver Federal Center \\ Denver, CO 80225 \\ 1strickland@usgs.gov
}


SAMPLE TABLES $2-8$. 
Table 2. Reference table; sample data.

\begin{tabular}{|c|c|}
\hline REFNUM & FULL REFERENCE \\
\hline $1 \mathrm{~m}$ & $\begin{array}{l}\text { Betancourt, J. L., and Davis, O. K. (1984). Packrat middens from Canyon de Chelly, } \\
\text { Northeastern Arizona: Paleoecological and Archaeological Implications. Quaternary } \\
\text { Research 21, 56-64. }\end{array}$ \\
\hline $2 \mathrm{~m}$ & $\begin{array}{l}\text { Betancourt, J. L., and Van Devender, T. R. (1981). Holocene vegetation in Chaco } \\
\text { Canyon, New Mexico. Science 214, 656-658. }\end{array}$ \\
\hline $3 \mathrm{~m}$ & $\begin{array}{l}\text { Betancourt, J. L. (1984). Late Quaternary plant zonation and climate in southeastern } \\
\text { Utah. Great Basin Naturalist 44, 1-35. }\end{array}$ \\
\hline $4 \mathrm{~m}$ & $\begin{array}{l}\text { Bright, R. C., and Davis, O. K. (1982). Quaternary paleoecology of the Idaho } \\
\text { National Engineering Laboratory, Snake River Plain, Idaho. American Midland } \\
\text { Naturalist 108,21-33. }\end{array}$ \\
\hline $5 \mathrm{~m}$ & $\begin{array}{l}\text { Cole, K. L., and Webb, R. H. (1985). Late Holocene vegetation changes in } \\
\text { Greenwater Valley, Mojave Desert, California. Quaternary Research 23, 227-235. }\end{array}$ \\
\hline $6 \mathrm{~m}$ & $\begin{array}{l}\text { Cole, K. L. (1981). Late Quaternary Environment in the Eastern Grand Canyon: } \\
\text { Vegetational Gradients Over the Last 25,000 Years. Unpublished Ph.D. thesis, } \\
\text { University of Arizona. }\end{array}$ \\
\hline $7 \mathrm{~m}$ & $\begin{array}{l}\text { Cole, K. L. (1983). Late Pleistocene vegetation of Kings Canyon, Sierra Nevada, } \\
\text { California. Quaternary Research 19, 117-129. }\end{array}$ \\
\hline $8 \mathrm{~m}$ & $\begin{array}{l}\text { Cole, K. L. (1986). The Lower Colorado Valley: a Pleistocene Desert. Quaternary } \\
\text { Research 25, 392-400. }\end{array}$ \\
\hline $9 \mathrm{~m}$ & $\begin{array}{l}\text { King, T. K., Jr.. (1976). Late Pleistocene - Early Holocene history of coniferous } \\
\text { woodlands in the Lucerne Valley Region, Mohave Desert, California. Great Basin } \\
\text { Naturalist 36, 227-238. }\end{array}$ \\
\hline $10 \mathrm{~m}$ & $\begin{array}{l}\text { Lanner, R. M., and Van Devender, T. R. (1974). Morphology of pinyon pine needles } \\
\text { from fossil packrat middens in Arizona. Forest Science 20,207-211. }\end{array}$ \\
\hline
\end{tabular}


Table 3. Midden sample sites table; sample data.

\begin{tabular}{|c|c|c|c|c|c|c|c|c|c|c|c|c|}
\hline SAMCODE & SITE & SAMPLE & DATA & $\begin{array}{c}\text { LAT } \\
\text { DEG(1) }\end{array}$ & $\begin{array}{c}\text { LAT } \\
\text { MIN(1) }\end{array}$ & $\begin{array}{c}\text { LAT } \\
\text { SEC(1) }\end{array}$ & $\begin{array}{c}\text { LONG } \\
\text { DEG(1) }\end{array}$ & $\begin{array}{l}\text { LONG } \\
\text { MIN(1) }\end{array}$ & $\begin{array}{l}\text { LONG } \\
\text { SEC(1) }\end{array}$ & SOURCE(1) & $\operatorname{ELEV}(\mathrm{m}) 1$ & SOURCE1 \\
\hline $\mathrm{AC} 2 \mathrm{~A}$ & Arch Cave & $\# 2 \mathrm{~A}$ & $\mathrm{X}$ & 39 & 17 & & 114 & 5 & & & 1980 & \\
\hline $\mathrm{AC4}$ & Arch Cave & $\# 4$ & $\mathrm{X}$ & 39 & 17 & & 114 & 5 & & & 1980 & \\
\hline AC6 & Arch Cave & $\# 6$ & $\mathrm{X}$ & 39 & 17 & & 114 & 5 & & & 1980 & \\
\hline AC8 & Arch Cave & $\# 8$ & $\mathrm{X}$ & 39 & 17 & & 114 & 5 & & & 1980 & \\
\hline AC9 & Arch Cave & $\# 9$ & $\mathrm{X}$ & 39 & 17 & & 114 & 5 & & & 1980 & \\
\hline AL1A & Ajo Loop & $1 \mathrm{~A}$ & $\mathrm{X}$ & 31 & 58 & & 112 & 47 & & & 550 & \\
\hline AL1D & Ajo Loop & $1 \mathrm{D}$ & $\mathrm{X}$ & 31 & 58 & & 112 & 47 & & & 550 & \\
\hline AL1G & Ajo Loop & $1 \mathrm{G}$ & $\mathrm{X}$ & 31 & 58 & & 112 & 47 & & & 550 & \\
\hline AL2B & Ajo Loop & $2 \mathrm{~B}$ & $\mathrm{X}$ & 31 & 58 & & 112 & 47 & & & 550 & \\
\hline AL2C & Ajo Loop & $2 \mathrm{C}$ & $\mathrm{X}$ & 31 & 58 & & 112 & 47 & & & 550 & \\
\hline AL3A & Ajo Loop & $3 \mathrm{~A}$ & $\mathrm{X}$ & 31 & 58 & & 112 & 47 & & & 550 & \\
\hline AL4 & Ajo Loop & 4 & $\mathrm{X}$ & 31 & 58 & & 112 & 47 & & & 550 & \\
\hline AL5B & Ajo Loop & $5 \mathrm{~B}$ & $\mathrm{X}$ & 31 & 58 & & 112 & 47 & & & 535 & \\
\hline AL6B & Ajo Loop & $6 \mathrm{~B}$ & $\mathrm{X}$ & 31 & 58 & & 112 & 47 & & & 550 & \\
\hline AL6C & Ajo Loop & $6 \mathrm{C}$ & $\mathrm{X}$ & 31 & 58 & & 112 & 47 & & & 550 & \\
\hline BASIN1 & Basin Canyon & $\# 1$ & $X$ & 36 & 42 & & 115 & 16 & & & 1635 & \\
\hline BASIN2A & Basin Canyon & $\# 2 \mathrm{~A}$ & $\mathrm{X}$ & 36 & 42 & & 115 & 16 & & & 1630 & \\
\hline BASIN2B & Basin Canyon & $\# 2 \mathrm{~B}$ & $\mathrm{X}$ & 36 & 42 & & 115 & 16 & & & 1630 & \\
\hline GA1 & Garrison & $\# 1$ & $\mathrm{X}$ & 38 & 57 & & 114 & 3 & & & 1640 & \\
\hline GA2 & Garrison & $\# 2$ & $\mathrm{X}$ & 38 & 57 & & 114 & 3 & & & 1640 & \\
\hline NBM1 & Newberry Mountain & $\# 1$ & $\mathrm{X}$ & 35 & 16 & & 114 & 37 & & & 850 & \\
\hline NBM2 & Newberry Mountain & $\# 2$ & $X$ & 35 & 16 & & 114 & 37 & & & 850 & \\
\hline
\end{tabular}


Table 3 - Continued.

\begin{tabular}{|c|c|c|c|c|c|c|c|c|c|}
\hline SAMCODE & REFERENCE1 & REFNUM1 & REFERENCE2 & REFNUM2 & COMMENTS & LOCALITY & $\begin{array}{c}\text { USE } \\
\text { STATUS } \\
\end{array}$ & STATE & COUNTY \\
\hline $\mathrm{AC} 2 \mathrm{~A}$ & Thompson, 1984 & $30 \mathrm{~m}$ & & & 99999 & Snake Range & 1 & $\mathrm{NV}$ & White Pine \\
\hline $\mathrm{AC} 4$ & Thompson, 1984 & $30 \mathrm{~m}$ & & & 99999 & Snake Range & 1 & NV & White Pine \\
\hline AC6 & Thompson, 1984 & $30 \mathrm{~m}$ & & & 99999 & Snake Range & 1 & $\mathrm{NV}$ & White Pine \\
\hline $\mathrm{AC} 8$ & Thompson, 1984 & $30 \mathrm{~m}$ & & & 99999 & Snake Range & 1 & NV & White Pine \\
\hline AC9 & Thompson, 1984 & $30 \mathrm{~m}$ & & & 99999 & Snake Range & 1 & $\mathrm{NV}$ & White Pine \\
\hline AL1A & Van Devender, 1987 & $56 \mathrm{~m}$ & & & 99999 & Puerto Blanco Mountains & 1 & $\mathrm{AZ}$ & Pima \\
\hline AL1D & Van Devender, 1987 & $56 \mathrm{~m}$ & & & 99999 & Puerto Blanco Mountains & 1 & $\mathrm{AZ}$ & Pima \\
\hline AL1G & Van Devender, 1987 & $56 \mathrm{~m}$ & & & 99999 & Puerto Blanco Mountains & 1 & $\mathrm{AZ}$ & Pima \\
\hline AL2B & Van Devender, 1987 & $56 \mathrm{~m}$ & & & 99999 & Puerto Blanco Mountains & 1 & $\mathrm{AZ}$ & Pima \\
\hline AL2C & Van Devender, 1987 & $56 \mathrm{~m}$ & & & 99999 & Puerto Blanco Mountains & 1 & $\mathrm{AZ}$ & Pima \\
\hline AL3A & Van Devender, 1987 & $56 \mathrm{~m}$ & & & 99999 & Puerto Blanco Mountains & 1 & $\mathrm{AZ}$ & Pima \\
\hline AL4 & Van Devender, 1987 & $56 \mathrm{~m}$ & & & 99999 & Puerto Blanco Mountains & 1 & $\mathrm{AZ}$ & Pima \\
\hline AL5B & Van Devender, 1987 & $56 \mathrm{~m}$ & & & 99999 & Puerto Blanco Mountains & 1 & $\mathrm{AZ}$ & Pima \\
\hline AL6B & Van Devender, 1987 & $56 \mathrm{~m}$ & & & 99999 & Puerto Blanco Mountains & 1 & $\mathrm{AZ}$ & Pima \\
\hline AL6C & Van Devender, 1987 & $56 \mathrm{~m}$ & & & 99999 & Puerto Blanco Mountains & 1 & $\mathrm{AZ}$ & Pima \\
\hline BASIN1 & Spaulding, 1981 & $24 \mathrm{~m}$ & & & 99999 & Sheep Range & 1 & NV & Clark \\
\hline BASIN2A & Spaulding, 1981 & $24 \mathrm{~m}$ & Spaulding, 1980 & $23 \mathrm{~m}$ & $\begin{array}{l}\text { The taxa list is from } \\
\text { Spaulding, } 1981\end{array}$ & Sheep Range & 1 & NV & Clark \\
\hline BASIN2B & Spaulding, 1981 & $24 \mathrm{~m}$ & Spaulding, 1980 & $23 \mathrm{~m}$ & $\begin{array}{l}\text { The taxa list is from } \\
\text { Spaulding, } 1981\end{array}$ & Sheep Range & 1 & NV & Clark \\
\hline GA1 & Thompson, 1984 & $30 \mathrm{~m}$ & Thompson And Mead, 1982 & $27 \mathrm{~m}$ & $\begin{array}{l}\text { The taxa list is from } \\
\text { Thompson, } 1984\end{array}$ & Snake Valley & 1 & NV & White Pine \\
\hline GA2 & Thompson, 1984 & $30 \mathrm{~m}$ & Thompson And Mead, 1982 & $27 \mathrm{~m}$ & $\begin{array}{l}\text { The taxa list is from } \\
\text { Thompson, } 1984\end{array}$ & Snake Valley & 1 & NV & White Pine \\
\hline NBM1 & Leskinen, 1975 & $11 \mathrm{~m}$ & Van Devender and Spaulding, 1979 & $36 \mathrm{~m}$ & $\begin{array}{l}\text { The taxa list is from } \\
\text { Leskinen, } 1975\end{array}$ & Newberry Mountains & -9 & NV & Clark \\
\hline $\mathrm{NBM} 2$ & Leskinen, 1975 & $11 \mathrm{~m}$ & & & 99999 & Mojave Desert & -9 & NV & Clark \\
\hline
\end{tabular}


Table 4. Age ${ }^{14} \mathrm{C}$ table; sample data. (Please note: MS Access does not allow us to italicize scientific names.)

\begin{tabular}{|l|r|r|r|l|l|l|}
\hline SAMCODE & C14AGE & STANDEV & \multicolumn{1}{|c|}{ LABNO } & MATERIAL DATED & \multicolumn{1}{|c|}{ COMMENTS } & REFERENCE \\
\hline A & 9320 & 300 & UCLA-644 & matrix & 99999 & $50 \mathrm{~m}, 55 \mathrm{~m}$ \\
\hline A1 & 10250 & 200 & A-1099 & Juniperus sp. twigs & 99999 & $42 \mathrm{~m}, 14 \mathrm{~m}$ \\
\hline A2 & 18320 & 400 & A-1101 & $\begin{array}{l}\text { Juniperus osteosperma and } \\
\text { Juniperus monosperma twigs }\end{array}$ & 99999 & $42 \mathrm{~m}, 14 \mathrm{~m}$ \\
\hline & & & & & $\begin{array}{l}\text { 1st run produced insufficient gas volume for } \\
\text { a count. A 2nd run produced a very young } \\
\text { age on very little gas and may be in error. }\end{array}$ \\
A2 & 1840 & 200 & A-1103 & Pinus monophylla needles & 14m \\
\hline A3 & $>30000$ & 9999 & A-1100 & Juniperus osteosperma twigs & 99999 & $36 \mathrm{~m}, 42 \mathrm{~m}, 14 \mathrm{~m}$ \\
\hline A3 & 21000 & 400 & USGS-196 & Juniperus sp. & 99999 & $36 \mathrm{~m}$ \\
\hline
\end{tabular}


Table 5. Midden taxa table; sample data. (Please note: MS Access does not allow us to italicize scientific names.)

\begin{tabular}{|c|c|c|c|c|c|c|c|}
\hline VARNUM & VARNAME & ORIGINAL SYNTAX & AUTHORITY 1 & \begin{tabular}{|c} 
CURRENTLY \\
ACCEPTED \\
NOMENCLATURE \\
\end{tabular} & AUTHORITY 2 & COMMON NAME & FAM ILY \\
\hline 273 & Abies lasiocarpa & & (Hook.) Nutt. & same & & subalpine fir & Pinaceae \\
\hline 354 & Abutilon cf. parvulum & & Gray & same & & dwarf indian mallow & Malvaceae \\
\hline 210 & Abutilon sp. & & Miller & same & & indian mallow & Malvaceae \\
\hline 205 & Amaranthus/Chenopodium & & L./L. & same & & amaranth, pigweed/goosefoot & Amaranthaceae/Chenopodiaceae \\
\hline 717 & Apiaceae & & & same & & carrot family & Apiaceae \\
\hline 848 & Atriplex spinosa & & (Hook.) Collotzi & Grayia spinosa & (Hook.) Moq. & spiny hop-sage & Chenopodiaceae \\
\hline 810 & Avena/Festuca-type & Avena sp./Fesuca sp. type & L./L. & same & & oats/fescue & Poaceae \\
\hline 241 & Artemisia tridentata-type & Artemisia tridentata (type) & Nutt. & same & & common sagebrush & Asteraceae \\
\hline
\end{tabular}


Table 6. Taxa per site table; sample data.

\begin{tabular}{|c|c|c|c|c|}
\hline SAMCODE & VARNUM & M COUNT & TYPE & NOTES \\
\hline A & 24 & ++ & leaves, twis, flowers & \\
\hline A & 25 & + & fruits & \\
\hline A & 33 & + & leaves, achenes & \\
\hline $\mathrm{A}$ & 42 & + & areoles, fruits, seeds & \\
\hline A & 139 & +++ & leafy twigs, seeds, wood & \\
\hline A & 140 & + & fruits & \\
\hline A & 1254 & + & leaves & \\
\hline $\mathrm{A}$ & 244 & + & leaves, calyces, achenes & \\
\hline $\mathrm{A}$ & 246 & ++ & twigs, seeds & \\
\hline A & 391 & + & leaves, seeds & \\
\hline A & 409 & + & leaves & \\
\hline A & 429 & + & leaves & \\
\hline A & 444 & + & achenes & \\
\hline A & 469 & + & leaves & \\
\hline A & 511 & + & involucres & \\
\hline $\mathrm{A}$ & 594 & + & involucres & \\
\hline A & 596 & + & leaves, fruits & \\
\hline A & 602 & + & fruits & \\
\hline A & 606 & + & leaves, twigs, flowers, seeds & \\
\hline A & 616 & + & leaves, seeds & \\
\hline $\mathrm{A}$ & 923 & + & leaves, capsules & \\
\hline A & 569 & ++ & leaves, drupes & \\
\hline A1 & 31 & $*$ & spines & \\
\hline A1 & 38 & $* * *$ & twigs, seeds & \\
\hline A1 & 90 & $* *$ & leaves, thorns & \\
\hline A1 & 1330 & $*$ & leaf fragments & \\
\hline A1 & 341 & $* *$ & twigs, seeds & \\
\hline A1 & 458 & $*$ & achenes & \\
\hline A1 & 1447 & $*$ & fruit, spine & \\
\hline A1 & 576 & $* *$ & leaves & \\
\hline
\end{tabular}


Table 7. Code translation table; sample data.

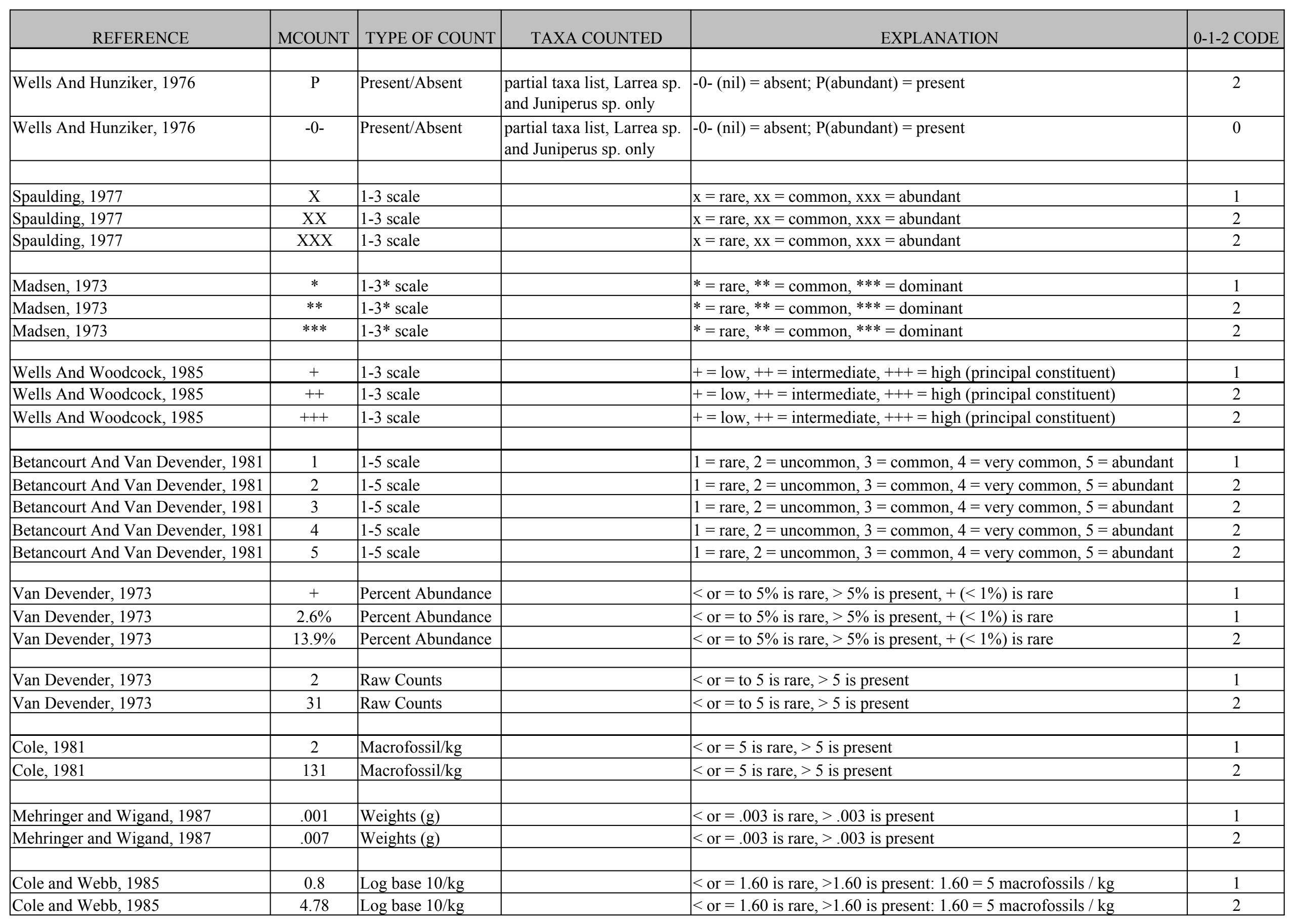


Table 8. M Count translation table; sample data.

\begin{tabular}{|c|c|c|c|}
\hline SAMCODE & VARNUM & M COUNT & 0-1-2 CODE \\
\hline A & 429 & + & 1 \\
\hline $\mathrm{A}$ & 569 & ++ & 2 \\
\hline A & 139 & +++ & 2 \\
\hline A & 25 & + & 1 \\
\hline $\mathrm{A}$ & 33 & + & 1 \\
\hline A & 42 & + & 1 \\
\hline A & 140 & + & 1 \\
\hline A & 1254 & + & 1 \\
\hline A & 244 & + & 1 \\
\hline $\mathrm{A}$ & 246 & ++ & 2 \\
\hline A & 409 & + & 1 \\
\hline A & 24 & ++ & 2 \\
\hline $\mathrm{A}$ & 444 & + & 1 \\
\hline A & 469 & + & 1 \\
\hline A & 511 & + & 1 \\
\hline A & 594 & + & 1 \\
\hline A & 596 & + & 1 \\
\hline $\mathrm{A}$ & 602 & + & 1 \\
\hline A & 606 & + & 1 \\
\hline A & 616 & + & 1 \\
\hline A & 923 & + & 1 \\
\hline $\mathrm{A}$ & 391 & + & 1 \\
\hline A1 & 1330 & $*$ & 1 \\
\hline A1 & 576 & $* *$ & 2 \\
\hline A1 & 341 & $* *$ & 2 \\
\hline A1 & 90 & $* *$ & 2 \\
\hline A1 & 1447 & $*$ & 0 \\
\hline A1 & 458 & $*$ & 1 \\
\hline A1 & 31 & $*$ & 1 \\
\hline A1 & 38 & $* * *$ & 2 \\
\hline
\end{tabular}




\section{REFERENCES}

Birks, H J.B. and Birks, H.H., 1980, Plant Macrofossils: Quaternary Palaeoecology, University Park Press, Baltimore, p. 66-84.

Finley, R.B., Jr., 1990. Woodrat Ecology and Behavior and the Interpretation of Paleomiddens. In Betancourt, J.L., Van Devender, T.R., and Martin, P.S. (eds.) "Packrat Middens: The Last 40,000 Years of Biotic Change". University of Arizona Press. pp. 28-42.

Kartesz, J.T., 1999. A Synonymized Checklist and Atlas with Biological Attributes for the Vascular Flora of the United States, Canada, and Greenland. First Edition. In Kartesz, J.T. and C. A. Meacham, Synthesis of the North American Flora, Version 1.0, North Carolina Botanical Garden, Chapel Hill, NC.

North American Pollen Database Manual, 1997.

Spaulding, W.G., Betancourt, J.L., Croft, L.K., and Cole, K.L., 1990. Packrat Middens: Their Composition and Methods of Analysis. In Betancourt, J.L., Van Devender, T.R., and Martin, P.S. (eds.) "Packrat Middens: The Last 40,000 Years of Biotic Change”. University of Arizona Press. pp. 59-84.

Vaughan, T.A., 1990. Ecology of Living Packrats. In Betancourt, J.L., Van Devender, T.R., and Martin, P.S. (eds.) "Packrat Middens: The Last 40,000 Years of Biotic Change”. University of Arizona Press. pp. 14-27.

Watts, W.A., and Winter, T.C., 1966. Plant macrofossils from Kirchner Marsh, Minnesota - A paeoecological Study. Geological Society of America Bulletin, v. 77, p. $1339-1360$. 
